\title{
Sistem Pakar Untuk Menentukan Status Pertumbuhan Pada Anak Menggunakan Inferensi Fuzzy (Sugeno)
}

\author{
Emi Agustina *, Agus Sidiq Purnomo ** \\ ${ }^{*}$ Program Studi Sistem Informasi, Fakultas Teknologi Informasi, Universitas Mercu Buana Yogyakarta \\ ${ }^{* *}$ Program Studi Teknik Informatika, Fakultas Teknologi Informasi, Universitas Mercu Buana \\ Yogyakarta \\ ${ }^{1}$ agustinaemi17@gmail.com, ${ }^{2}$ sidiq@mercubuana-yogya.ac.id
}

\begin{abstract}
ABSTRAK
The detection of child growth should be done as early and as accurately as possible, so that if there is a deviation of child growth can be known earlier and can be found a solution to the deviation.

In the examination of children who performed in pharmacies depok sleman pengelolahan data inspection done manually so that data is not well recorded, it causes the data is lost and not clear. For that we need a system capable of data menguin so as to minimize the things that are not desirable.

In this study, the researchers aimed to create an expert system that gives an idea of the growth in children with fuzzy logic motede which requires several variables, namely age, height, gender and weight which will be taken z-score weight and z- Score height.

Based on the test result which has been done with 85 examination data of children, it can be concluded that the implementation of fuzzy sugeno method can be used as a determination of the status of the child's growth with total accuracy of $81.18 \%$.
\end{abstract}

Keyword: Child, Growth, Expert System, Fuzzy Inference, Sugeno

\section{Introduction}

Pertumbuhan merupakan suatu perubahan dalam ukuran tubuh dan merupakan sesuatu yang dapat diukur seperti tinggi badan, berat badan, lingkar kepala yang dapat dibaca pada buku pertumbuhan. Pendeteksian pertumbuhan anak harus dilakukan sedini dan seakurat mungkin, sehingga apabila ada penyimpangan pertumbuhan anak dapat diketahui lebih dini dan dapat dicarikan solusi atas penyimpangan tersebut. Peran seorang pakar sangat dibutuhkan untuk mendeteksi adanya penyimpangan pada pertumbahan namun demikian, keterbatasan waktu yang dimiliki seorang pakar terkadang menjadi kendala bagi yang akan melakukan konsultasi guna menyelesaikan suatu permasalahan untuk mendapatkan solusi terbaik.

Pada pemeriksaan anak yang dilakukan di apotik depok sleman masih dilakukan secara manual sehingga data tidak terdata dengan baik, hal itu menyebabkan adanya data yang hilang dan tidak jelas. Untuk itu perlu adanya sistem yang mampu mengeloa data sehingga meminimalisir hal yang tidak diinginkan.

Pada pemeriksaan anak yang dilakukan dibeberapa apotik masih dilakukan secara manual sehingga data tidak terdata dengan baik, hal itu menyebabkan adanya data yang hilang dan tidak jelas. Untuk itu perlu adanya sistem yang mampu mengeloa data sehingga meminimalisir hal yang tidak diinginkan.

Berdasarkan uraian di atas, maka peneliti dalam hal ini mengambil judul "Sistem Pakar Untuk Menentukan Status Pertumbuhan Pada Anak Dengan Infrensi Fuzzy (Sugeno)“ menggunakan parameterparameter tertentu yang nantinya dapat memberikan kemudahan bagi pengguna dalam menentukan status pertumbuhan anak.

Beberapa penelitian yang terkait seperti pada penelitian "Sistem Pakar Pertumbuhan Balita Berbasis Web Dengan Metode Case Based Reasoning “, mengembangkan sistem pakar dengan Metode Case Based Reasoning (CBR) dan Perhitungan yang digunakan yaitu Nearest Neighbor, dimana data kasus baru akan dibandingkan perhitungannya dengan data kasus lama yang ada di database, selanjutnya dihitung kriteria kemiripannya berdasarkan rumus atau ketentuan yang berlaku. Selanjutnya hasil database dapat menghasilkan data keluaran yang berupa perbandingan antara kasus lama dengan kasus baru untuk penentuan kriteria kemiripan kasus pertumbuhan balita yang dipengaruhi oleh jenis kelamin, usia, berat badan dan tinggi badan [1].

Pada penelitian lain mengenai "Sistem Pendukung Keputusan Untuk Menentukan Status Gizi Balita Menggunakan Metode Fuzzy Inferensi Sugeno (Berdasarkan Metode Antropometri)", mengembangkan sistem penunjang keputusan dengan metode fuzzy sugeno berdasarkan metode antropometri diperoleh hasil bahwa perhitungan sistem dengan metode fuzzy Sugeno dan perhitungan menggunakan standar baku antropometri memiliki hasil $84 \%$ dari 25 data yang diujikan terdapat 4 yang tidak sesuai, sehingga dapat disimpulkan bahwa 
unjuk kerja sistem berhasil [2].

Sistem pakar adalah sebuah kecerdasan buatan yang terdapat dalam sebuah perangkat lunak yang dibangun dengan kemampuan mendekati seorang pakar (manusia) yang memiliki pengetahuan tinggi dalam sebuah bidang tertentu yang diharapkan dapat membantu memecahkan sebuah masalah. Seorang pakar adalah orang yang mempunyai keahlian dalam bidang tertentu. Pemrosesan yang dilakukan oleh sistem pakar merupakan pemrosesan pengetahuan (knowledge). Knowledge adalah pemahaman secara praktis maupun teoritis terhadap suatu obyek atau domain tertentu. Knowledge dalam sistem pakar bisa saja seorang ahli, atau knowledge yang umumnya terdapat dalam buku, majalah dan orang yang mempunyai pengetahuan tentang suatu bidang. Knowledge yang digunakan pada sistem pakar merupakan serangkaian informasi mengenai gejala-diagnosa, sebab-akibat, aksi-reaksi tentang suatu domain tertentu (misalnya, domain diagnosa medis) [3].

Sistem inferensi fuzzy merupakan kerangka komputasi yang didasarkan pada teori himpunan fuzzy, aturan fuzzy berbentuk IF-THEN, dan penalaran fuzzy. Dalam penalaran fuzzy metode Sugeno terdapat dua model yaitu : (1) Model Fuzzy Sugeno Orde-Nol, (2) Model Fuzzy Sugeno Orde-Satu. Tahapan dalam model fuzzy sugeno antara lain : (1) Pembentukan himpunan fuzzy, (2) Aplikasi fungsi implikasi, dan (3) Defuzzifikasi [4].

Model fuzzy Sugeno merupakan pendekatan sistematis pembangkitan aturan fuzzy dari himpunan data masukan-masukan yang diberikan [5].

Rumusan permasalah didefinisikan dalam penelitian ini adalah bagaimana membuat sebuah prototipe dan menerapkan fuzzy inferensi (sugeno) pada untuk menentukan status pertumbuhan pada anak?

Penelitian ini bertujuan untuk membuat aplikasi sistem pakar dan dapat mengimplementasikan metode fuzzy inferensi (Mamdani) untuk menentukan status pertumbuhan pada anak.

Hasil dari penelitian ini diharapkan dapat memberikan manfaat sebagai alternatif media untuk membantu mengetahui status pertumbuhan pada anak. Sehingga masyarakat umum dapat mengetahui status tumbuh kembang pada anak.

\section{Research Method}

Metode pengumpulan data yang digunakan dalam penelitian ini yaitu sebagai berikut (a) Mempelajari Literatur dengan mempelajari konsep-konsep yang berkaitan dengan pembuatan penelitian ini, seperti konsep tehnik infrensi fuzzy, mempelajari jurnal, dan sumber ilmiah lain seperti internet dan buku. (b) Metode Wawancara yang dilakukan untuk mendapatkan data serta pengetahuan yang lebih akurat tentang pertumbuhan anak berdasarkan pengalaman dokter spesialis anak dilapangan. Wawancara lebih ditekankan untuk mengetahui cara menentukan status pertumbuhan anak yang normal dan tidak normal.

Jalan penelitian dapat dilihat pada Gambar 1.

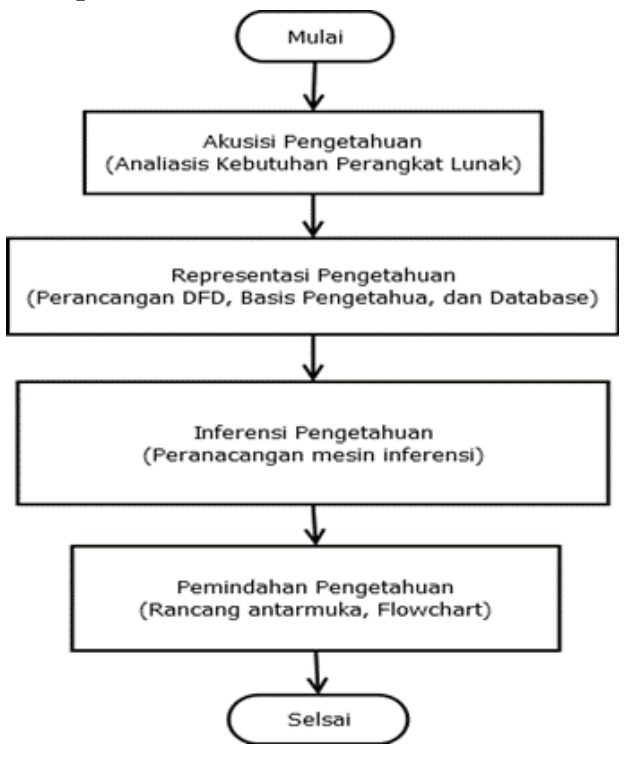

Gambar 1. Desain Sistem

\subsection{Analisis Kebutuhan Masukan}

Dokter Spesialis anak memberi masukkan berupa: (1) Data pokok tersebut meliputi usia anak, tinggi anak dan berat badan anak. (2) Perhitungan dalam penentuan normal atau tidak normal pertumbuhan pada 
anak menggunakan perhitungan z-score. (3) Data keanggotaan yang digunakan untuk himpunan fuzzy belum ada dalam sistem. (4) Data aturan ditambahkan dalam sistem disesuaikan dengan aturan. (5) Dari keempat aturan tersebut digunakan sebagai basis pengetahuan dari Sistem Pakar Untuk Menentukan Status Pertumbuhan Pada Anak Dengan Infrensi Fuzzy (Sugeno). Basis aturan yang digunakan dapat dilihat pada tabel 1.

Tabel 1. Tabel Basis Aturan

\begin{tabular}{|c|c|c|c|c|c|}
\hline No. & & Gender & Berat Badan And Tinggi Anak And Usia Anak & & Status Pertumbuahan \\
\hline 1 & IF & $\mathrm{P}$ & Rendah $A N D \quad$ Ringan $A N D$ Anak awal & THEN & Normal \\
\hline 2 & IF & $\mathrm{P}$ & Sedang $A N D$ Anak awal & THEN & Normal \\
\hline 3 & IF & $\mathrm{P}$ & Berat $A N D$ Anak awal & THEN & Tidak Normal \\
\hline 4 & IF & $\mathrm{P}$ & Ringan $A N D$ Anak akhir & THEN & Normal \\
\hline 5 & IF & $\mathrm{P}$ & Sedang $A N D$ Anak akhir & THEN & Tidak Normal \\
\hline 6 & IF & $\mathrm{P}$ & Berat $A N D$ Anak akhir & THEN & Tidak Normal \\
\hline 7 & IF & $\mathrm{P}$ & Ringan $A N D$ Pubertas & THEN & Tidak Normal \\
\hline 8 & IF & $\mathrm{P}$ & Sedang $A N D$ Pubertas & THEN & Tidak Normal \\
\hline 9 & IF & $\mathrm{P}$ & Berat $A N D$ Pubertas & THEN & Tidak Normal \\
\hline 10 & IF & $\mathrm{P}$ & Agak Tinggi $A N D$ Ringan $A N D$ Anak awal & THEN & Normal \\
\hline 11 & IF & $\mathrm{P}$ & Agak Tinggi $A N D$ Sedang $A N D$ Anak awal & THEN & Normal \\
\hline 12 & IF & $\mathrm{P}$ & Agak Tinggi $A N D$ Berat $A N D$ Anak awal & THEN & Normal \\
\hline 13 & IF & $\mathrm{P}$ & Agak Tinggi $A N D$ Ringan $A N D$ Anak akhir & THEN & Tidak Normal \\
\hline 14 & IF & $\mathrm{P}$ & Agak Tinggi $A N D$ Sedang $A N D$ Anak akhir & THEN & Normal \\
\hline 15 & IF & $\mathrm{P}$ & Agak Tinggi $A N D$ Berat $A N D$ Anak akhir & THEN & Normal \\
\hline 16 & IF & $\mathrm{P}$ & Agak Tinggi $A N D$ Ringan $A N D$ Pubertas & THEN & Tidak Normal \\
\hline 17 & IF & $\mathrm{P}$ & Agak Tinggi $A N D$ Sedang $A N D$ Pubertas & THEN & Normal \\
\hline 18 & IF & $\mathrm{P}$ & Agak Tinggi $A N D$ Berat $A N D$ Pubertas & THEN & Normal \\
\hline 19 & IF & $\mathrm{P}$ & Tinggi $A N D \quad$ Ringan $A N D$ Anak awal & THEN & Tidak Normal \\
\hline 20 & IF & $\mathrm{P}$ & Sedang $A N D$ Anak awal & THEN & Normal \\
\hline 21 & IF & $\mathrm{P}$ & Berat $A N D$ Anak awal & THEN & Tidak Normal \\
\hline 22 & IF & $\mathrm{P}$ & Ringan $A N D$ Anak akhir & THEN & Normal \\
\hline 23 & IF & $\mathrm{P}$ & Sedang $A N D$ Anak akhir & THEN & Normal \\
\hline 24 & IF & $\mathrm{P}$ & Berat $A N D$ Anak akhir & THEN & Normal \\
\hline 25 & IF & $\mathrm{P}$ & Ringan $A N D$ Pubertas & THEN & Tidak Normal \\
\hline 26 & IF & $\mathrm{P}$ & Sedang $A N D$ Pubertas & THEN & Normal \\
\hline 27 & IF & $\mathrm{P}$ & Berat $A N D$ Pubertas & THEN & Normal \\
\hline 28 & IF & $\mathrm{L}$ & Ringan $A N D$ Anak awal & THEN & Normal \\
\hline 29 & IF & $\mathrm{L}$ & Sedang $A N D$ Anak awal & THEN & Normal \\
\hline 30 & IF & $\mathrm{L}$ & Berat $A N D$ Anak awal & THEN & Tidak Normal \\
\hline 31 & IF & $\mathrm{L}$ & Ringan $A N D$ Anak akhir & THEN & Normal \\
\hline 32 & IF & $\mathrm{L}$ & Sedang $A N D$ Anak akhir & THEN & Tidak Normal \\
\hline 33 & IF & $\mathrm{L}$ & Berat $A N D$ Anak akhir & THEN & Tidak Normal \\
\hline 34 & IF & $\mathrm{L}$ & Ringan $A N D$ Pubertas & THEN & Tidak Normal \\
\hline 35 & IF & $\mathrm{L}$ & Sedang $A N D$ Pubertas & THEN & Tidak Normal \\
\hline 36 & IF & $\mathrm{L}$ & Berat $A N D$ Pubertas & THEN & Tidak Normal \\
\hline 37 & IF & $\mathrm{L}$ & Agak Tinggi $A N D$ Ringan $A N D$ Anak awal & THEN & Normal \\
\hline 38 & $\mathrm{IF}$ & $\mathrm{L}$ & Agak Tinggi $A N D$ Sedang $A N D$ Anak awal & THEN & Normal \\
\hline 39 & IF & $\mathrm{L}$ & Agak Tinggi $A N D$ Berat $A N D$ Anak awal & THEN & Normal \\
\hline 40 & IF & $\mathrm{L}$ & Agak Tinggi $A N D$ Ringan $A N D$ Anak akhir & THEN & Tidak Normal \\
\hline 41 & IF & $\mathrm{L}$ & Agak Tinggi $A N D$ Sedang $A N D$ Anak akhir & THEN & Normal \\
\hline 42 & $\mathrm{IF}$ & $\mathrm{L}$ & Agak Tinggi $A N D$ Berat $A N D$ Anak akhir & THEN & Normal \\
\hline 43 & IF & $\mathrm{L}$ & Agak Tinggi $A N D$ Ringan $A N D$ Pubertas & THEN & Tidak Normal \\
\hline 44 & IF & $\mathrm{L}$ & Agak Tinggi $A N D$ Sedang $A N D$ Pubertas & THEN & Normal \\
\hline 45 & $\mathrm{IF}$ & $\mathrm{L}$ & Agak Tinggi $A N D$ Berat $A N D$ Pubertas & THEN & Normal \\
\hline 46 & IF & $\mathrm{L}$ & Tinggi $A N D \quad$ Ringan $A N D$ Anak awal & THEN & Tidak Normal \\
\hline 47 & IF & $\mathrm{L}$ & Sedang $A N D$ Anak awal & THEN & Normal \\
\hline 48 & $\mathrm{IF}$ & $\mathrm{L}$ & Berat $A N D$ Anak awal & THEN & Tidak Normal \\
\hline 49 & $\mathrm{IF}$ & $\mathrm{L}$ & Ringan $A N D$ Anak akhir & THEN & Normal \\
\hline 50 & IF & $\mathrm{L}$ & Sedang $A N D$ Anak akhir & THEN & Normal \\
\hline 51 & $\mathrm{IF}$ & $\mathrm{L}$ & Berat $A N D$ Anak akhir & THEN & Normal \\
\hline 52 & IF & $\mathrm{L}$ & Ringan $A N D$ Pubertas & THEN & Tidak Normal \\
\hline 53 & IF & $\mathrm{L}$ & Sedang $A N D$ Pubertas & THEN & Normal \\
\hline 54 & IF & $\mathrm{L}$ & Berat $A N D$ Pubertas & THEN & Normal \\
\hline
\end{tabular}




\subsection{Desain}

\subsubsection{Flowchart System}

Perancangan jalannya sistem dapat dilihat pada Gambar 2.

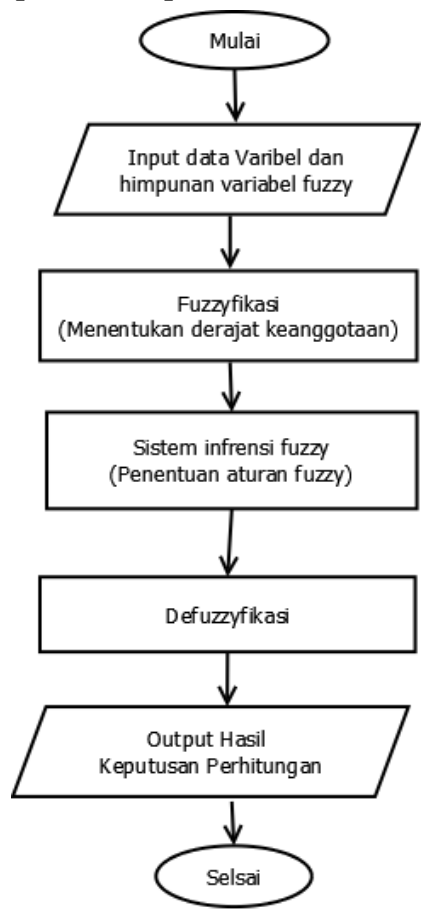

Gambar 2. Flowchart System

\subsubsection{Context Diagram}

Context Diagram dalam penelitian ini dapat dilihat pada Gambar 3.

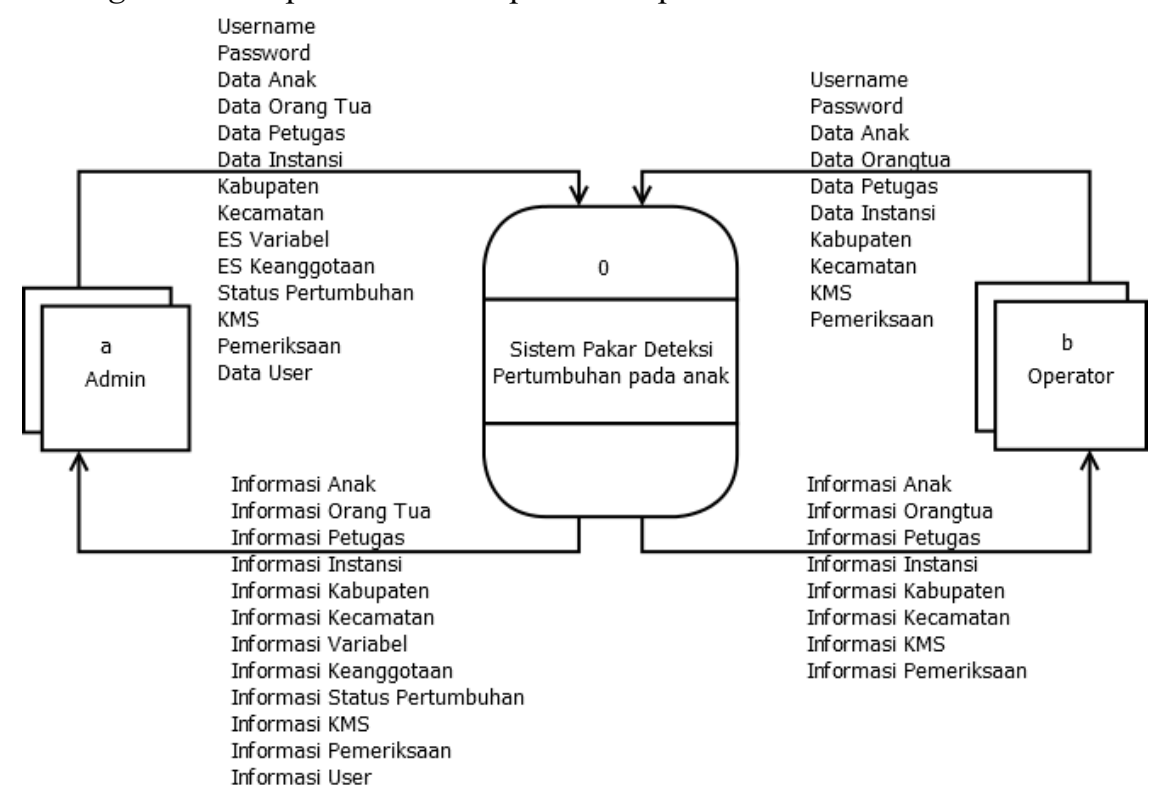

Gambar 3. Data Flow Diagram Level 0

\subsubsection{Perancangan Database}

Relasi tabel dalam penelitian ini, dapat dilihat pada Gambar 4. 


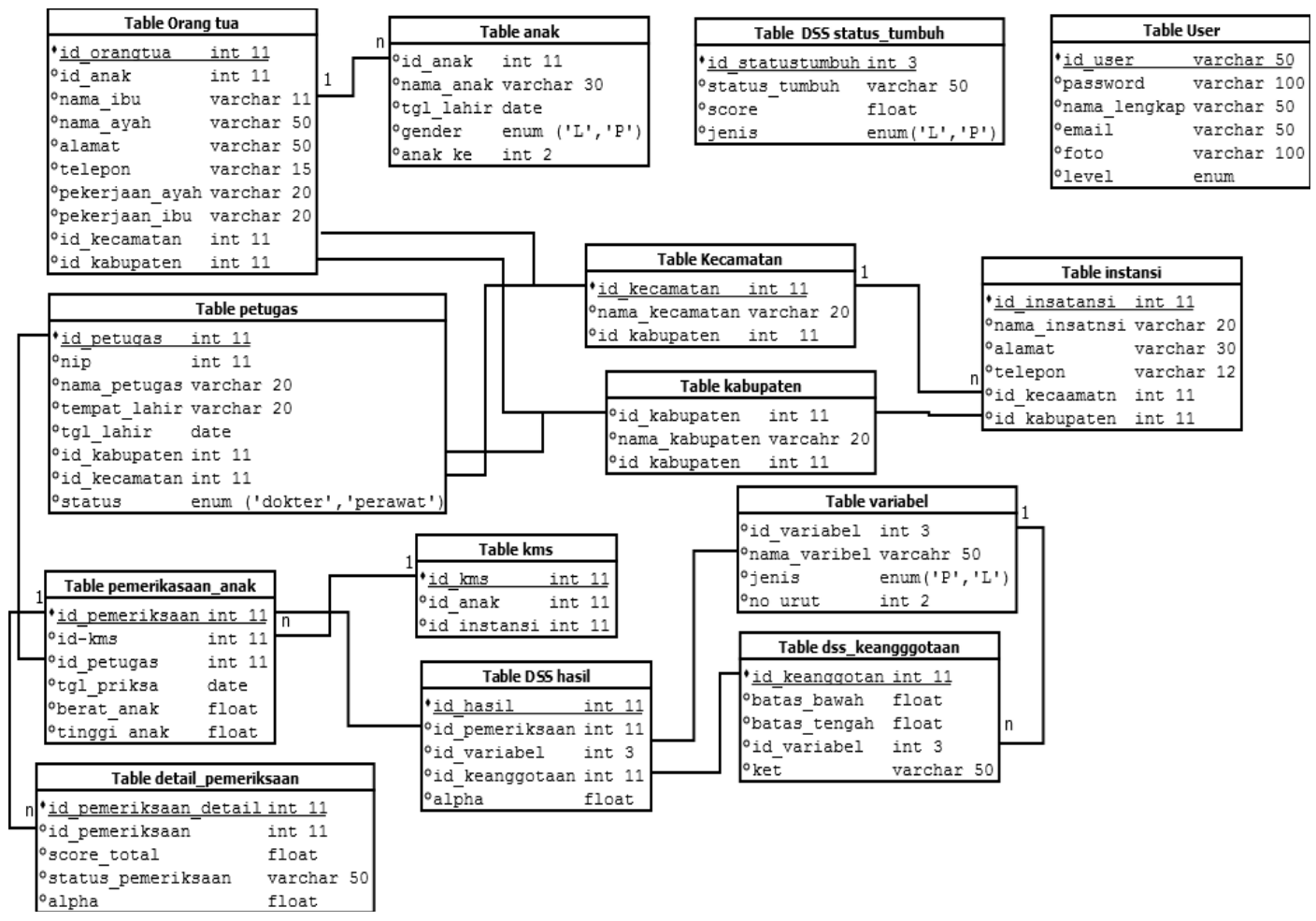

Gambar 4. Relasi Tabel

\subsection{Inferensi Pengetahuan}

Metode fuzzy Sugeno dimulai dari pembentukan Himpunanan pada setiap variabel kemudian selanjutnya proses perhitungan inferensi dan terakhir proses deffuzifikasi dengan perhitungan z-score untuk satus pertumbuhan pada anak. Dalam proses fuzzifikasi harus membuat perancangan himpunan fuzzy pada sistem pakar deteksi pertumbuhan anak adalah sebagai berikut :

1. Varibel umur

Variabel umur dibagi menjadi tiga fase (tiga himpunan fuzzy), dapat dilihat pada Gambar 5.

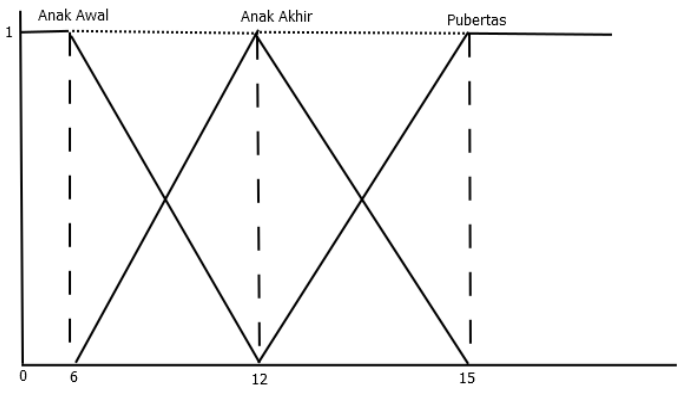

Usia (dalam tahun)

Gambar 5. Variabel Usia

2. Varibel berat badan

Variabel berat badan dibedakan menjadi dua berdasarkan jenis kelamin anak, yaitu laki-laki dan perempuan, dapat dilihat pada Gambar 6.
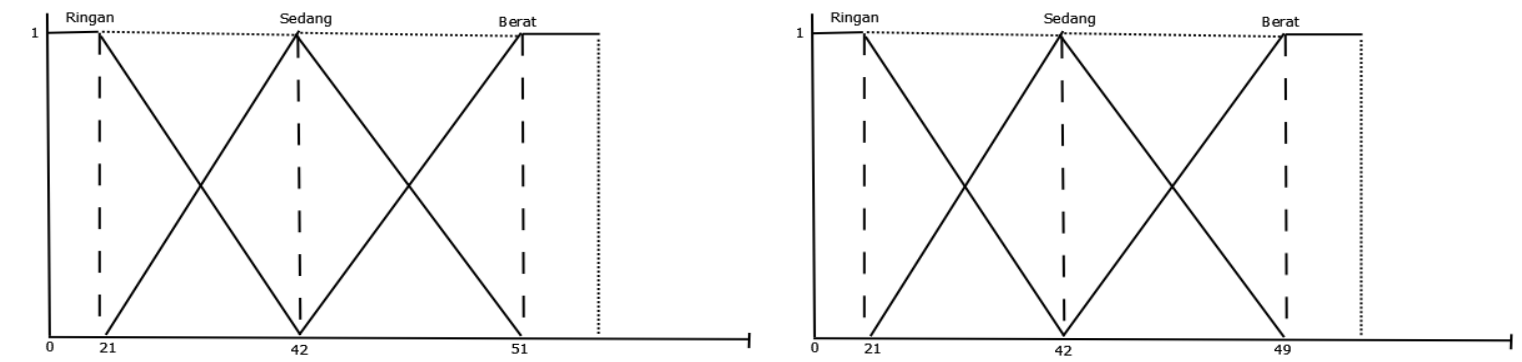
(a)

(b)

Gambar 6. Variabel Berat Badan (a) Laki-Laki, (b) Perempuan

3. Varibel tinggi badan

Variabel tinggi badan dibedakan menjadi dua berdasarkan jenis kelamin anak, yaitu laki-laki dan perempuan, dapat dilihat pada Gambar 7.

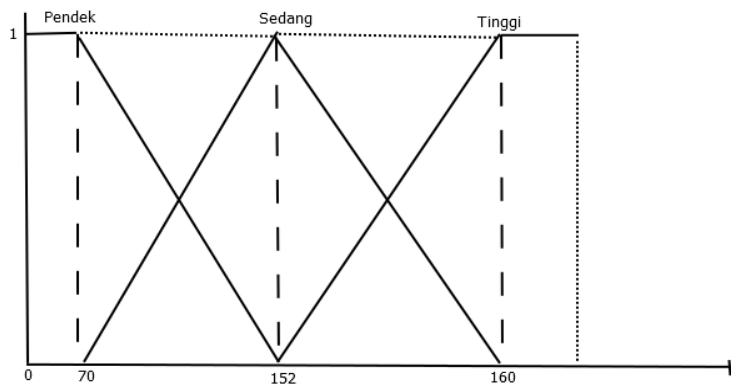

(a)

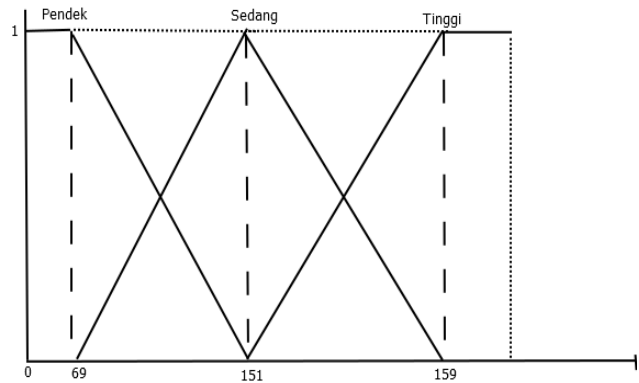

(b)

Gambar 7. Variabel Tinggi Badan (a) Laki-Laki, (b) Perempuan

4. Variabel status pertumbuhan

Variabel status pertumbuhan dibagi menjadi dua fase (dua himpunan fuzzy), dapat dilihat pada Gambar 8.

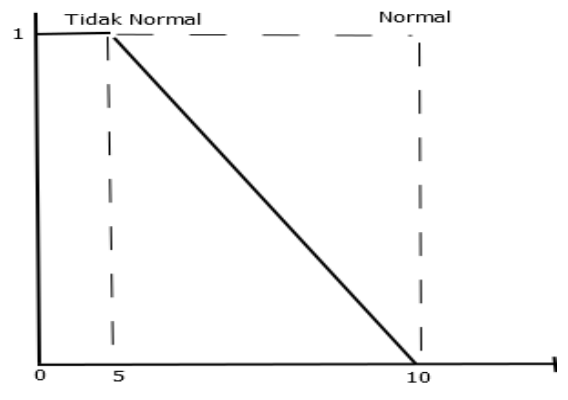

Gambar 8. Variabel status pertumbuhan

\section{Result and Analysis}

\subsection{Data Kasus}

Anaslisis sistem dilakukan dengan membandingkan basil penentuan status pertumbuhan anak menggunakan data pemeriksaan dari pakar dengan basil perhitungan penentuan status pertumbuahan anak menggunakan metode fuzzy inferensi (Sugeno). Perhitungan penentuan status pertumbuahan anak pada sistem menggunakan tiga variabel yaitu berat badan anak, usia anak dan tinggi anak. Hasil perhitungan dengan mengacu pada data anak Tabel 2 dapat dilihat pada hasil tiap proses perhitungannya.

Proses fuzzifikasi dengan menggunakan data pemeriksaan anak pada Tabel 2, dalam hal ini mengambil salah satu sampel data pemeriksaan anak.

\section{Tabel 2. Sampel Data Pengujian}

\begin{tabular}{ccccccc}
\hline No & Nama & Tgl.Lahir & Tanggal Periksa & Umur (thn) & BB (kg) & TB (cm) \\
\hline $\mathbf{1}$ & Mikhayla Aryila S.P & 28-Jul-16 & 10 -Oct-16 & 0.16 & 5.5 & 60 \\
\hline
\end{tabular}

\section{2 fuzzifikasi}

Hasil proses fuzzifikasi oleh sistem pakar dapat dilihat pada Gambar 9. 
Detail Pemeriksaan Anak

\section{Anak}

Nama Anak:

Mikhayla Aryila S.P

Tanggal Pemeriksaan

100 ct 2016

\section{A. Proses Fuzzifikasi}

Merubah nilai crips variabel Tingg, Berat dan Usia Anak menjadi nilai fuzzy (nilai $\alpha=$ derajat keanggotaan), berdasarkan aturan fuzzy yang telah didefinisikan.

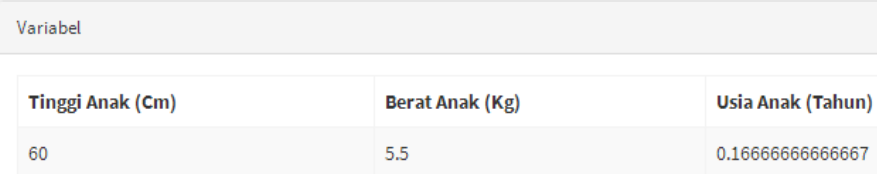

Nilai Alpha (Derajat Keanggotaan)

No. Variabel Keterangan Derajat Keanggotaan

1 Berat Badan $\quad$ Ringan 0.74

Tinggi Rendah $\quad 1.12$

Usia $\quad$ Awal 1.97

Gambar 9. Fuzzyfikasi

Perhitungan fuzzifikasi adalah sebagai berikut :

a. Usia

Pada data pemeriksaan dari Tabel 1 didapat usia anak 2 bulan sehingga diidentifikasikan anggota himpunan variabel usia Anak Awal. Derajat keanggotaan usia untuk kategori Anak Awal menggunakan rumus :

$$
\begin{aligned}
& \mu \text { Usia Anak Awal }=x-1 / 12-6 \\
& \mu \text { Usia Anak Awal }=2-1 / 6 \\
& \mu \text { Usia Anak Awal }=0,167
\end{aligned}
$$

maka nilai derajat keanggotaan Usia Anak pada kategori Anak Awal adalah 0,167.

b. Berat Badan

Berat badan anak 5,9 kg berada pada keanggotaan berat badan pada kategori RINGAN . Derajat keanggotaan berat badann untuk kategori RINGAN menggunakan rumus :

$$
\begin{aligned}
& \mu \text { BB RINGAN }=21-\mathrm{x} / 42-21 \\
& \mu \text { BB RINGAN }=21-5,5 / 21 \\
& \mu \text { BB RINGAN }=0,74
\end{aligned}
$$

maka nilai derajat keanggotaan Berat Badan pada kategori RINGAN adalah 0,719.

c. Tinggi Badan

Tinggi Badan Anak $60 \mathrm{~cm}$ berada pada keanggotaan tinggi badan pada kategori RENDAH. Derajat keanggotaan tinggi badan untuk kategori RENDAH menggunakan rumus :

$$
\begin{aligned}
& \mu \text { TB RENDAH }=151-\mathrm{x} / 151-70 \\
& \mu \text { TB RENDAH }=151-60 / 82 \\
& \mu \text { TB RENDAH }=1,12
\end{aligned}
$$

maka nilai derajat keanggotaan Tinggi Badan pada kategori RENDAH adalah 1,1219.

\subsection{Inferensi}

Proses inferensi dalam sistem dapat dilihat pada Gambar 10. 


B. Proses Inferensi
Jumlah Variabel $(\alpha)=3$
1. Berat $=$ Ringan $(0.74)$
2. Tinggi $=$ Rendah $(1.12)$
3. Usia = Awal $(1.97)$

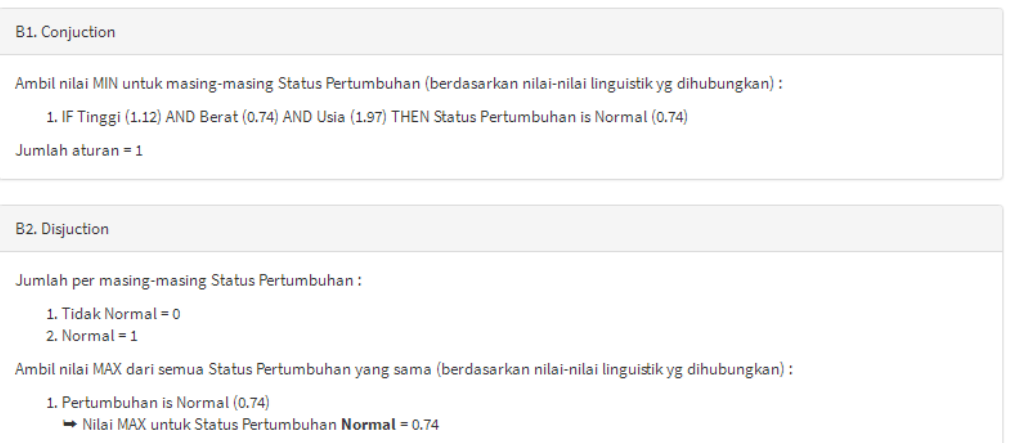

Gambar 10. Inferensi

Proses fuzzifikasi menghasilkan tiga jumalah data yaitu :

$$
\begin{array}{ll}
\text { Berat RINGAN } & =0,74 \\
\text { Tinggi PENDEK } & =1,12 \\
\text { Usia AWAL } & =1,97
\end{array}
$$

Dari ketiga fuzzifikasi tersebut didapatkan satu aturan yang dapat diaplikasikan dengan menggunakan aturan dengan memilih derjat keanggotaan minimum dari nilai-nilai linguistik yang dihubungkan oleh $(\cap)$ dan dilakukan clipping pada fungsi keanggotaan trapesium untuk menentukan status pertumbuhan anak :

IF Berat RINGAN $(0,74)$ AND Tinggi PENDEK $(1,12)$ AND Usia AWAL $(1,97)$ THEN status pertumbuhan NORMAL

Dengan demikian diperoleh jumlah tiap masing-masing status pertumbuhan anak sebagai berikut :

- $\quad$ Tidak normal $=0$

- $\quad$ Normal $=1$

Kemudian proses dilanjutkan dengan melakukan komposisi aturan (Disjunction) dengan mengambil nilai maksimum dari status pertumbuhan anak yang sama ( berdasarkan nilai-nilai linguistik yang dihubungkan). Sehingga didapat aturan sebagai berikut :

- Pertumbuhan is $\operatorname{Normal}(0,74) \rightarrow$ Nilai $M A X$ untuk Status Pertumbuhan normal $=0,74$.

\subsection{Defuzzyfikasi}

Proses defuzzifikasi menggunakan sistem dapat dilihat pada Gambar 11.
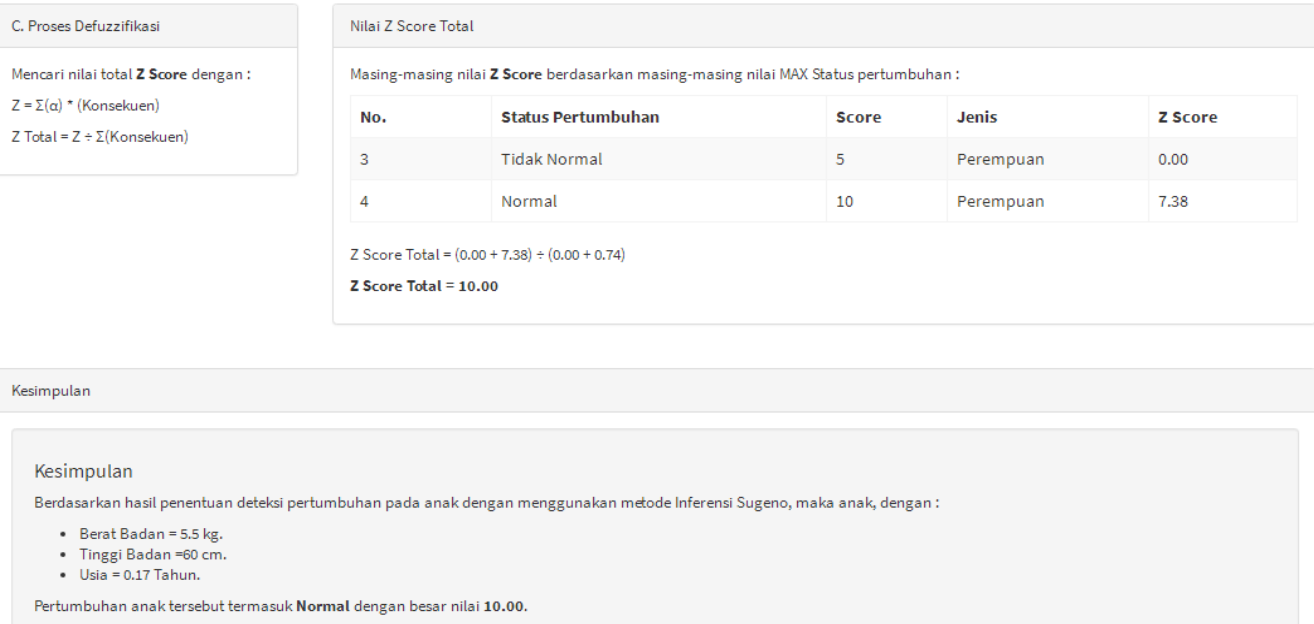

Gambar 11. Defuzzifikasasi 
Defuzzifikasi menggunakan model sugeno yaitu menghitung nilai total z-score yang selanjutnya mengambil nilai $z$-score berdasarkan nilai $M A X$ dari status pertumbuhan, tabel nilai $z$-score dapat dilihat pada Tabel 3.

Tabel 3. Nilai Z-Score

\begin{tabular}{|c|c|c|c|c|}
\hline No & Status Pertumbuhan & Score & Jenis & Z Score \\
\hline 1 & Tidak Normal & 5 & Perempuan & 0.00 \\
\hline 2 & Normal & 10 & Perempuan & 7,38 \\
\hline
\end{tabular}

Berdasarkan perhitungan total $z$-score yang telah dilakukan status pertumbuhan anak dengan nilai max adalah NORMAL $(7,38)$. Jadi dapat disimpulkan anak dengan nama Mikhayla Aryila S.P dengan berat badan $5.6 \mathrm{~kg}$, tinggi badan $60 \mathrm{~cm}$, dan usia 0,17 tahun, status pertumbuahan NORMAL.

\subsection{Validasi Hasil}

Validasi hasil dengan menunjukkan perbandingan penentuan status pertumbuhan anak sesuai dengan saran pakar dibandingkan dengan sistem menggunakan metode fuzzy dapat dilihat pada Tabel 4 .

Tabel 4. Validasi Hasil

\begin{tabular}{|c|c|c|c|c|c|c|}
\hline \multirow{2}{*}{ No } & \multirow{2}{*}{ Nama } & \multirow{2}{*}{$\begin{array}{c}\text { Tanggal } \\
\text { Lahir }\end{array}$} & \multirow[b]{2}{*}{$\begin{array}{c}\text { Tanggal } \\
\text { Priksa }\end{array}$} & \multicolumn{2}{|c|}{ Hasil Diagnosis } & \multirow{2}{*}{$\begin{array}{c}\text { Validasi } \\
\text { (Sesuai / Tidak) }\end{array}$} \\
\hline & & & & Pakar & Sistem & \\
\hline 1 & M. Afnan Naufal S & 29-Sep-04 & 30-Aug-16 & Tidak & Normal & Tidak \\
\hline 2 & M. Afnan Naufal S & 29-Sep-04 & 13-Jan-16 & Tidak & Normal & Tidak \\
\hline 3 & M. Afnan Naufal S & 29-Sep-04 & 23-Aug-15 & Tidak & Normal & Tidak \\
\hline 4 & M. Afnan Naufal S & 29-Sep-04 & 28-May-12 & Tidak & Normal & Tidak \\
\hline 5 & M. Afnan Naufal S & 29-Sep-04 & 6-Dec-10 & Tidak & Normal & Tidak \\
\hline 6 & M. Afnan Naufal S & 29-Sep-04 & 16-Jan-10 & Tidak & Normal & Tidak \\
\hline 7 & M. Afnan Naufal S & 29-Sep-04 & 29-Mar-09 & Normal & Normal & Sesuai \\
\hline 8 & M. Afnan Naufal S & 29-Sep-04 & 15-Aug-08 & Normal & Normal & Sesuai \\
\hline 9 & M. Afnan Naufal S & 29-Sep-04 & 19-Mar-08 & Normal & Normal & Sesuai \\
\hline 10 & M. Afnan Naufal S & 29-Sep-04 & 11-Feb-08 & Normal & Normal & Sesuai \\
\hline 11 & M. Afnan Naufal S & 29-Sep-04 & 21-Aug-07 & Normal & Normal & Sesuai \\
\hline 12 & M. Afnan Naufal S & 29-Sep-04 & 21-Dec-06 & Normal & Normal & Sesuai \\
\hline 13 & M. Afnan Naufal S & 29-Sep-04 & $1-N o v-06$ & Normal & Normal & Sesuai \\
\hline 14 & M. Afnan Naufal S & 29-Sep-04 & 5-Oct-06 & Normal & Normal & Sesuai \\
\hline 15 & M. Afnan Naufal S & 29-Sep-04 & 30-Sep-06 & Normal & Normal & Sesuai \\
\hline 16 & M. Afnan Naufal S & 29-Sep-04 & 28-Aug-06 & Tidak & Normal & Tidak \\
\hline 17 & M. Afnan Naufal S & 29-Sep-04 & 5-Aug-06 & Normal & Normal & Sesuai \\
\hline 18 & M. Afnan Naufal S & 29-Sep-04 & 4-Jul-06 & Normal & Normal & Sesuai \\
\hline 19 & M. Afnan Naufal S & 29-Sep-04 & 6-Jun-06 & Normal & Normal & Sesuai \\
\hline 20 & M. Afnan Naufal S & 29-Sep-04 & 8-May-06 & Normal & Normal & Sesuai \\
\hline 21 & M. Afnan Naufal S & 29-Sep-04 & 11-Apr-06 & Normal & Normal & Sesuai \\
\hline 22 & M. Afnan Naufal S & 29-Sep-04 & 20-Dec-05 & Normal & Normal & Sesuai \\
\hline 23 & M. Afnan Naufal S & 29-Sep-04 & 29-Sep-05 & Normal & Normal & Sesuai \\
\hline 24 & M. Afnan Naufal S & 29-Sep-04 & 18-Jul-05 & Normal & Normal & Sesuai \\
\hline 25 & M. Afnan Naufal S & 29-Sep-04 & 29-Apr-05 & Normal & Normal & Sesuai \\
\hline 26 & M. Afnan Naufal S & 29-Sep-04 & 9-Mar-05 & Normal & Normal & Sesuai \\
\hline 27 & Surya Tyaga Bimantara & 13-Mar-10 & 15-Nov-16 & Normal & Normal & Sesuai \\
\hline 28 & Surya Tyaga Bimantara & 13-Mar-10 & 29-Jul-16 & Tidak & Normal & Tidak \\
\hline 29 & Surya Tyaga Bimantara & 13-Mar-10 & 16-Apr-16 & Tidak & Normal & Tidak \\
\hline 30 & Khoirun Mustaffa & 21-Dec-11 & 15-Nov-16 & Normal & Normal & Sesuai \\
\hline 31 & Khoirun Mustaffa & 21-Dec-11 & 11-Oct-16 & Normal & Normal & Sesuai \\
\hline 32 & Khoirun Mustaffa & 21-Dec-11 & $10-$ Oct-16 & Normal & Normal & Sesuai \\
\hline 33 & Khoirun Mustaffa & 21-Dec-11 & 3-Sep-16 & Normal & Normal & Tidak \\
\hline 34 & Khoirun Mustaffa & 21-Dec-11 & 24-Feb-16 & Normal & Normal & Sesuai \\
\hline 35 & Khoirun Mustaffa & 21-Dec-11 & 18-Jan-16 & Normal & Normal & Sesuai \\
\hline 36 & Khoirun Mustaffa & 21-Dec-11 & 19-Sep-15 & Normal & Normal & Sesuai \\
\hline 37 & Khoirun Mustaffa & 21-Dec-11 & 6-Jun-15 & Normal & Normal & Sesuai \\
\hline 38 & Khoirun Mustaffa & 21-Dec-11 & 26-Mar-14 & Normal & Normal & Sesuai \\
\hline 39 & Khoirun Mustaffa & 21-Dec-11 & 26-Feb-14 & Normal & Normal & Sesuai \\
\hline 40 & Khoirun Mustaffa & 21-Dec-11 & 28-Nov-13 & Normal & Normal & Sesuai \\
\hline 41 & Khoirun Mustaffa & 21-Dec-11 & 3-Oct-13 & Normal & Normal & Sesuai \\
\hline 42 & Khoirun Mustaffa & 21-Dec-11 & 17-Jun-13 & Normal & Normal & Sesuai \\
\hline 43 & Khoirun Mustaffa & 21-Dec-11 & 6-May-13 & Normal & Normal & Sesuai \\
\hline 44 & Khoirun Mustaffa & 21-Dec-11 & $20-F e b-13$ & Normal & Normal & Sesuai \\
\hline 45 & Khoirun Mustaffa & 21-Dec-11 & 11-Feb-13 & Normal & Normal & Sesuai \\
\hline 46 & Khoirun Mustaffa & 21-Dec-11 & 21-Jan-13 & Normal & Normal & Sesuai \\
\hline 47 & Khoirun Mustaffa & 21-Dec-11 & 18-Jan-13 & Normal & Normal & Sesuai \\
\hline
\end{tabular}




\begin{tabular}{|c|c|c|c|c|c|c|}
\hline \multirow{2}{*}{ No } & \multirow{2}{*}{ Nama } & \multirow{2}{*}{$\begin{array}{c}\text { Tanggal } \\
\text { Lahir }\end{array}$} & \multirow[b]{2}{*}{$\begin{array}{c}\text { Tanggal } \\
\text { Priksa }\end{array}$} & \multicolumn{2}{|c|}{ Hasil Diagnosis } & \multirow{2}{*}{$\begin{array}{c}\text { Validasi } \\
\text { (Sesuai / Tidak) }\end{array}$} \\
\hline & & & & Pakar & Sistem & \\
\hline 48 & Khoirun Mustaffa & 21-Dec-11 & 10-Jan-13 & Normal & Normal & Sesuai \\
\hline 49 & Khoirun Mustaffa & 21-Dec-11 & 13-Nov-12 & Normal & Normal & Sesuai \\
\hline 50 & Khoirun Mustaffa & 21-Dec-11 & 2-Nov-12 & Normal & Normal & Sesuai \\
\hline 51 & Khoirun Mustaffa & 21-Dec-11 & 4-Sep-12 & Normal & Normal & Sesuai \\
\hline 52 & Khoirun Mustaffa & 21-Dec-11 & 9-Apr-12 & Normal & Normal & Sesuai \\
\hline 53 & Khoirun Mustaffa & 21-Dec-11 & $28-F e b-12$ & Normal & Normal & Sesuai \\
\hline 54 & Khoirun Mustaffa & 21-Dec-11 & 8 -Feb-12 & Tidak & Normal & Tidak \\
\hline 55 & Khoirun Mustaffa & 21-Dec-11 & 19-Jan-12 & Normal & Normal & Sesuai \\
\hline 56 & Khoirun Mustaffa & 21-Dec-11 & 28-Dec-11 & Normal & Normal & Sesuai \\
\hline 57 & Amira Zahra & 20-May-13 & 15-Nov-16 & Normal & Normal & Sesuai \\
\hline 58 & Amira Zahra & 20-May-13 & 16-Sep-15 & Normal & Normal & Sesuai \\
\hline 59 & Amira Zahra & 20-May-13 & 6-Apr-15 & Normal & Normal & Sesuai \\
\hline 60 & Amira Zahra & 20-May-13 & 10-Mar-14 & Tidak & Normal & Tidak \\
\hline 61 & Amira Zahra & 20-May-13 & 24-Feb-14 & Tidak & Normal & Tidak \\
\hline 62 & Amira Zahra & 20-May-13 & 23-Jan-14 & Tidak & Normal & Tidak \\
\hline 63 & Amira Zahra & 20-May-13 & 11-Jan-14 & Tidak & Normal & Tidak \\
\hline 64 & Amira Zahra & 20-May-13 & 24-Oct-13 & Normal & Normal & Sesuai \\
\hline 65 & Rajendra Mahasin S & $31-$ Oct-13 & 15-Jan-18 & Normal & Normal & Sesuai \\
\hline 66 & Rajendra Mahasin S & 31-Oct-13 & 15-Nov-16 & Normal & Normal & Sesuai \\
\hline 67 & Rajendra Mahasin S & 31-Oct-13 & $10-$-Oct-16 & Normal & Normal & Sesuai \\
\hline 68 & Rajendra Mahasin S & 31-Oct-13 & 29-Mar-16 & Normal & Normal & Sesuai \\
\hline 69 & Rajendra Mahasin S & 31-Oct-13 & 4-Nov-15 & Normal & Normal & Sesuai \\
\hline 70 & Rajendra Mahasin S & 31-Oct-13 & 25-Sep-15 & Normal & Normal & Sesuai \\
\hline 71 & Rajendra Mahasin S & 31-Oct-13 & 10-Sep-15 & Normal & Normal & Sesuai \\
\hline 72 & Rajendra Mahasin S & 31-Oct-13 & 24-Aug-15 & Normal & Normal & Sesuai \\
\hline 73 & Rajendra Mahasin S & 31-Oct-13 & 13-Jul-15 & Normal & Normal & Sesuai \\
\hline 74 & Rajendra Mahasin S & 31-Oct-13 & 8-Jul-15 & Normal & Normal & Sesuai \\
\hline 75 & Rajendra Mahasin S & 31-Oct-13 & 8-May-15 & Normal & Normal & Sesuai \\
\hline 76 & Rauf Al Faqih N & 24-Jan-14 & 15-Nov-16 & Normal & Normal & Sesuai \\
\hline 77 & Rauf Al Faqih N & 24-Jan-14 & 13-Jul-16 & Normal & Normal & Sesuai \\
\hline 78 & Rauf Al Faqih N & 24-Jan-14 & 27-Apr-16 & Normal & Normal & Sesuai \\
\hline 79 & Cataleye Bella AS & 12-May-14 & 15-Nov-16 & Normal & Normal & Sesuai \\
\hline 80 & Cataleye Bella AS & 12-May-14 & 6-Feb-16 & Tidak & Normal & Tidak \\
\hline 81 & Mikhayla Aryila S.P & 28-Jul-16 & 31-Oct-16 & Normal & Normal & Sesuai \\
\hline 82 & Mikhayla Aryila S.P & 28-Jul-16 & $13-O c t-16$ & Normal & Normal & Sesuai \\
\hline 83 & Mikhayla Aryila S.P & 28-Jul-16 & 10 -Oct-16 & Normal & Normal & Sesuai \\
\hline 84 & Shanum Andhara P & 11-Aug-16 & 15-Nov-16 & Normal & Normal & Sesuai \\
\hline 85 & Joshepine Odelia I. & $8-N o v-16$ & 15-Nov-16 & Normal & Normal & Sesuai \\
\hline
\end{tabular}

Berdasarkan data yang valid diperoleh hasil pengujian oleh sistem yaitu status pertumbuhan anak yang normal sebanyak 85 data dan untuk status pertumbuhan anak yang tidak normal terdapat 0 data. Sedangkan dari hasil validasi yang dilakukan oleh pakar (dokter) status pertumbuhan anak yang normal sebanyak 70 data dan untuk status pertumbuhan anak yang tidak normal terdapat 15 data.

Untuk tingkat kesesuaian berdasarkan hasil validasi pakar (dokter) dan sistem diperoleh $81,18 \%$ data yang sesuai dan $18,82 \%$ data uji yang tidak sesuai.

\section{Conclusion}

Berdasarkan data yang valid diperoleh hasil pengujian oleh sistem yaitu status pertumbuhan anak yang normal sebanyak 85 data dan untuk status pertumbuhan anak yang tidak normal terdapat 0 data. Sedangkan dari hasil validasi yang dilakukan oleh pakar (dokter) status pertumbuhan anak yang normal sebanyak 70 data dan untuk status pertumbuhan anak yang tidak normal terdapat 15 data. Untuk tingkat kesesuaian berdasarkan hasil validasi pakar (dokter) dan sistem diperoleh $81,18 \%$ data yang sesuai dan $18,82 \%$ data uji yang tidak sesuai.

Saran untuk pengembangan selanjutnya terhadap penelitian ini untuk menambahkan variabel lingkar kepala agar output yang dihasilkan lebih akurat.

\section{Acknowledgements}

dr. Th. Noor Widiastuti, Sp. A yang sudah banyak memberikan ilmu yang berharga tentang pertumbuhan anak

\section{References}

[1] M. Shaid, W. L. YS dan Y. R. Utami, "Sistem Pakar Pertumbuhan Balita Berbasis Web Dengan Metode Case Base Reasoning," Jurnal TiKomSiN, ISSN : 2338-4018, pp. 37-44. 
[2] A. Romadhon dan A. S. Purnomo, "Sistem Pendukung Keputusan Untuk Menentukan Status Gizi Balita Menggunakan Metode Fuzzy Inferensi Sugeno (Berdasarkan Metode Antropometri)," Informatics Journal, Vol. 1, No. 3, ISSN : ISSN 2503-250X, pp. 78-87, 2016.

[3] M. Arhami, Konsep Dasar Sistem Pakar, Yogyakarta: Andi, 2005.

[4] S. Kusumadewi dan H. Purnomo, Aplikasi Logika Fuzzy Untuk Pendukung Keputusan, Yogyakarta: Graha Ilmu, 2010.

[5] T. S. Widodo, Sistem Neuro Fuzzy, Yogyakarta: Graha Ilmu, 2005.

[6] S. Kusumadewi, Artificial Intelligent (Teknik dan Aplikasinya), Yogyakarta: Graha Ilmu, 2003. 